\title{
AN ANALYSIS ON THE SYNTACTICAL ERRORS IN THE STUDENTS' NARRATIVE WRITING
}

\author{
Zumrotul Muniroh; Fitri Senny Hapsari \\ English Education and Industrial Program Faculty of Language and Arts Education \\ University of Indraprasta PGRI \\ zumrotul_m@yahoo.com, fitrisennyhapsari@gmail.com
}

\begin{abstract}
This research aims to find out the syntactical errors made by the ninth grade students of Darul Hikmah II Junior High School in their narrative writing, to identify the dominant factor causing the syntactical errors of narrative writing and the students' errors made that can be corrected for improving their narrative writing ability, for the final goal is to improve learning quality of narrative writing. In this study writer limited the student's syntactical error only in phrase error. The approach applied in this study is qualitative. The data obtained through observation and giving narrative writing test. The writer used the descriptive analysis technique (percentage) with the percentage from the frequency of information and was divided with number of cases were constructed in the form of field-notes. This study involved twenty students of Darul Hikmah II Junior High School Bekasi as samples. The data shows that the total mistakes made by students in syntactical are 382 errors. The greatest number of students' errors was noun phrase $(42,4 \%)$, verb phrase errors by 139 errors $(36,4 \%)$, adverbial phrase errors by 42 errors (11\%), adjective phrase errors by 29 errors (7,6\%), and prepositional phrase with 6 errors $(30 \%)$.
\end{abstract}

key words: error analysis, syntactical, writing, narrative

\section{ABSTRAK}

Penelitian ini dilakukan untuk mengetahui kesalahan-kesalahan sintaksis yang dibuat oleh siswa kelas sembilan SMP Darul Hikmah II dalam penulisan narasi mereka, mengidentifikasi faktor dominan yang menyebabkan kesalahan sintaksis penulisan naratif dan kemudian kesalahan siswa yang telah dibuat dapat dikoreksi untuk meningkatkan kemampuan menulis narasi mereka, sehingga tujuan akhir dari penelitian ini dapat dimanfaatkan sebagai salah satu acuan dalam meningkatkan kualitas pembelajaran penulisan naratif. Dalam penelitian ini penulis membatasi kesalahan sintaksis siswa hanya dalam kesalahan prasa. Pendekatan yang digunakan dalam penelitian ini adalah kualitatif. Data diperoleh melalui observasi dan pemberian tes tulis naratif. Penulis menggunakan teknik analisis deskriptif (persentase) dengan persentase dari frekuensi informasi dan dibagi dengan jumlah kasus yang dikonstruksi dalam bentuk catatan lapangan. Penelitian ini melibatkan dua puluh siswa SMP Darul Hikmah II Bekasi sebagai sampel. Data menunjukkan bahwa jumlah total kesalahan yang dibuat oleh siswa dalam sintaksis adalah 382 kesalahan. Jumlah terbesar kesalahan siswa dilakukan dalam pembentukan prasa kata benda $(42,4 \%)$, kesalahan frasa kata kerja sebanyak 139 (36,4\%), kesalahan dalam pembentukan frasa kata 
keterangan sebanyak 42 kesalahan (11\%), kesalahan frasa kata sifat sebanyak 29 kesalahan (7,6\%) dan kesalahan frasa preposisi dengan 6 kesalahan (30\%).

kata kunci: analisis kesalahan, sintaksis, penulisan, narasi

coherence, grammar and unity in their writing activity.

\section{INTRODUCTION}

One of the foreign languages being learned by the students at school is English. At the time the position of English in Indonesia is first foreign language. The ministry of nation education has decided to establish the main purpose of the English Foreign Language Teaching in improving four skills; listening, speaking, reading, and writing. So the students should be able to master four English skills. Writing is very complex activity and difficult skill for L2 learners to master.

It lies not only in generating and organizing ideas, but also in translating these ideas into readable text. The skills involved in writing are highly complex. L2 writers have to pay attention to higher level skill of planning and organizing as well as lower level skills of spelling, punctuation, word choice, and so on. The difficulty becomes moree pronounced if their language proficiency is weak.

In order to understand how write a composition clearly and correctly in English students have to be supported by the mastery of two important subsystem or components of language, namely vocabulary and grammar at once. Nowadays, writing seems to the handicap and burden for the students at senior high school level. They think that writing is very difficult and complex part particularly in learning English; moreover, it requires not only having a lot of vocabularies but also considering the mechanisms of it. Based on the statement above, every student needs to understand how to combine vocabulary,
Writing is a continuous complex process of expressions. It is not itself a simple process with its native language and rather even more a complicated process if the language is a foreign language. A number of studies that students' first language gives interference during students' process of English writing.

Writing ability is English skills should be mastered by students, preceded by listening, speaking and reading. The writing is a complex skill to express ideas or feelings in correct, comprehensible and clear way. Often what the students write contain ideas that are not really relevant to what actually they want to express. It is clear that writing is not the same as speaking.

Speaking is a spontaneous activity but writing is conscious and complex activity which can and should be planned and organized The students commonly make some errors in their learning especially in writing. The teacher should analyze the errors made by students to help them write in the right way.

James (2001:1) stated that error analysis is the way to show, describe, and explain systematically errors made by learners or user in their oral or written production in learning the target of language. By those processes the students and the teacher will get advantages. The teacher can evaluate the learning process and find out the problems to help the students to understand English especially writing. There are mainly four types of error in students writing activity. They are as follows: lexical error, syntactic error, 
semantic error and logical error: such as infinitely recursive call.

This research provides the real phenomena that will be proved by the researcher. They refer to the error analysis in students' essay that will be analyzed by considering the mechanism of writing as well as the syntactical error. The main reason to only focus in this type of error because a text is determined legal by the language of syntax and the disagreements with the syntactic rules are called syntax error.

This judgment can easily be detected by our knowledge of language but one purpose of a theory of syntax is to possess the structural sentence as acceptable or not. Syntax complexity is one of the most difficult structural elements for ESL/EFL learners.

This research took the ninth grade students of SMP Darul Hikmah as sample. This school was a place where writers had been doing community service activity. At that time writers got informations from the English teachers about their difficulties in teaching English to their students. On that occasion they told us that one of their greatest challenges is how they teach students to produce English writing which is the complex ability to master in English skill.

Some references that the writers read earlier is Paramitha Kusumawardani's work (2015) said that everyone who studies English has exactly made some errors, it happens because English is not students' mother tongue they use in their daily life. They have made some errors like grammatical, word selection, and ordering errors. It gave the writers inspiration to do research with a similar theme but adapted to the schools' conditions and students' problems that obtained through interviews with the English teachers.
According to the curriculum in SMP Nurul Hikmah II Bekasi, writing in the ninth grade is taught into four kinds of texts: Descriptive, Narrative, Procedure, and News Item text. Narrative text was the text that used and analyzed in this research.

It referred to the error analysis in students' essay that analyzed by considering the mechanism of writing as well as the syntactical error. This research focuses on a discussion about finding out the writing errors made by the students using an error analysis. So the writer did research in the title "An Analysis on the Syntactical Errors in the Students' Narrative Writing" (A Case Study of the Ninth Grade Students of "SMP Darul Hikmah II Bekasi").

In linguistics, syntax is the set of rules, principles, and processes that govern the structure of sentences in a given language, specifically word order. The term syntax is also used to refer to the study of such principles and processes. Cristal David (2008: 83) states that syntax is a subfield of grammar. It is the study of the principles and rules for constructing phrases and sentences in language and the relationships between words.

According to Brinton (2010:59), "Syntax is the study of the principles and processes by which sentences are constructed in particular language". Syntactic investigation of a given language has as its goal the construction of a grammar that can be viewed on the device of some sort for producing these sentences of language under analysis.

Another definition of Syntax was explained by Fromkin, Rodman and Hyams (2006:40), "Syntax is the study about grammatical, principles, units and relations involved in sentence structures". From the explanation above we can conclude that syntax deals with how sentences are constructed, and 
users of human language employ a striking variety of possible arrangements of the element in sentences. It refers how to arrange the sentences in English.

In the arrangement of sentence, we should use the sentence pattern of English. Start from the smallest units to the main units. The hierarchy of sentence constituents. Morpheme Word Phrase Clause Sentence In this research the writers will examine syntactic relations within English sentences. One approach is to divide the words of a sentence into phrases (defined as words closely associated with one another syntactically). This technique is known as parsing.

The most fundamental division is between subject and predicate. (of course, this is because we are cheating and ignoring sentence types that lack this division). Phrases containing different parts of speech can serve one and the same function, just concern in analyzing into the types of phrase A phrase is a group or words that express a concept and is used as a unit within a sentence.

It is a group of related words (within a sentence) without both subject and verb. A phrase functions as a noun, verb, adverb, adjective or preposition in a sentence. The function of a phrase depends on its construction (words it contains). On the basis of their functions and constructions, phrases are divided into various types: noun phrase, verb phrase, adverb phrase, adjective phrase, appositive phrase, infinite phrase,

participle phrase and gerund phrase.

A noun phrase consists of a noun and other related words (usually modifiers and determiners) which modify the noun. It functions like a noun in a sentence. A noun phrase consists of a noun as the head word and other words (usually modifiers and determiners) which come after or before the noun. The whole phrase works as a noun in a sentence. Noun Phrase = noun + modifiers (the modifiers can be after or before noun). Example: $\mathrm{He}$ is wearing a nice red shirt. (as noun/object). A man on the roof was shouting. (as noun/subject) A prepositional phrase consists of a preposition, object of preposition (noun or pronoun) and may also consist of other modifiers, e.g. on a table, near a wall, in the room, at the door, under a tree. A prepositional phrase starts with a preposition and mostly ends with a noun or pronoun. Whatever prepositional phrase ends with is called object of preposition. A prepositional phrase functions as an adjective or adverb in a sentence. An adjective phrase is a group of words that functions like an adjective in a sentence.

It consists of adjectives, modifier and any word that modifies a noun or pronoun. An adjective phrase functions like an adjective to modify (or tell about) a noun or a pronoun in a sentence Prepositional phrases and participle phrases also function as adjectives so we can also call them adjective phrases when they function as adjective.

In the above sentence "The girl with brown hair is singing a song", the phrase "with brown hair" is a prepositional phrase but it functions as an adjective. An adverb phrase is a group of words that functions as an adverb in a sentence. It consists of adverbs or other words (preposition, noun, verb, modifiers) that make a group with works like an adverb in a sentence.

An adverb phrase functions like an adverb to modify a verb, an adjective or another adverb. A prepositional phrase can also act as an adverb phrase. 
For example in the above sentence "He always behaves in a good manner", the phrase "in a good manner" is a prepositional phrase but it acts as adverb phrase here. A verb phrase is a combination of main verb and its auxiliaries (helping verbs) in a sentence. Examples: "She has finished her work" and "You should study for the exam".

According to generative grammar, a verb phrase can consist of main verb, its auxiliaries, its complements and other modifiers. Hence it can refer to the whole predicate of a sentence. Example. You should study for the exam. In order to be able to write or to make a composition clearly and correctly in English, students have to be supported by the mastery of two important subsystems or components of language, namely vocabulary and grammar at once.

Although they have mastered the basic grammar, they still cannot convey their ideas without mastering an adequate knowledge of words and their meanings. Writing is one of the parts of language skills besides Listening, Speaking and Reading. Writing is more difficult rather then the other language skills because it needs well knowledge and hard thinking when they are produce words, sentences and paragraphs with a good grammatical.

In this study student write a narrative text which has social function to amuse, entertain and to deal with actual vicarious experience in different ways, narrative deal with problematic events which lead to a crisis or turning point of some kind, which in turn finds a resolution. There are many types of narrative. They can be imaginary, factual or a combination of both.

They may include fairy stories, mysteries, science fiction, romances, horror stories, adventure stories, fables, myths and legends, historical narratives, ballads, slice of life, personal experience. Generic Structures of Narrative Text: a) Orientation Sets the scene: where and when the story happened and introduces the participants of the story: who and what is involved in the story. b) Complication Tells the beginning of the problems which leads to the crisis (climax) of the main participants. c) Resolution The problem (the crisis) is resolved, either in a happy ending or in a sad (tragic) ending. d) Re-orientation/Coda This is a closing remark to the story and it is optional. It consists of a moral lesson, advice or teaching from the writer Language Features of Narrative Text Using past action verb : climbed, turned, brought, etc. Using specific noun as pronoun of person, animal in the story. Example : the king, the queen, etc. Using adjectives which are for noun phrase. Example: long black, two red apples, beautiful woman, etc. Using adverbs and adverbial phrase to show the location of events. Example: here in the mountain, ever after, etc. Using dialogue to elicit an emotional response from the reader. Using of variety of simple, compound and complex sentences.

\section{METHOD}

This study is designed by using the descriptive qualitative method, because it is basically trying to analyze, describe, and explain the data. Furthermore, the findings of this study are revealed not by tools of statistical procedures or other devices of quantification (Pallawa and Alam, 2013), the procedure of data collection was done by observation and recording.

The samples are 20 students to be analyzed at class IX A and IX B of SMP Darul Hikmah II To collect the data, writers used field research. To get field research, the writer got in touch 
directly with the students of SMP Darul Hikmah II. The writers give written test to the students of class IX A and IX B to find the information how much the students are able to make narrative text with good syntactical rules.

And writers also interview the English teacher to know their background of knowledge, the curriculum, method in English teaching learning and their difficulties in teaching their students. From the interview obtained that writing is still the hardest skill to be mastered by students. Commonly the students have made the errors in grammatical and sentence composition. The last the writers use descriptive analysis technique (percentage) with the percentage from the frequency of information and divided with number of cases. It shows which kind of error dominantly made by the students.

\section{RESULTS AND DISCUSSION}

To know the description of the syntactical errors in the students' writing, the researcher identify the the syntactical errors into types of phrase aspects: Adjective phrase, adverbial phrase, noun phrase, verb phrase and prepositional phrase. Then the researcher made the reconstruction of the errors' writing which made by the students.

Here are the tables which show us the identification, the classification and the reconstruction of the errors which made by the students. The researcher classified the students' syntactical errors in narrative writing. Then the researcher only focused on five areas: adjective phrase, adverbial phrase, noun phrase, verb phrase and prepositional phrase.

Here are the explanations about the calculation and interpretation of the data. Based on the analysis, it is shown that the total number of mistakes made in syntactical is 382 errors. The greatest number of students' errors was done in noun phrase with the percentage 42 , $4 \%$.

It indicates that the students feel difficult to arrange the parts of noun phrase in the right way. Most of students didn't write the correct composition of noun phrase. The common errors were made by students is wrong placement between adjective and noun, the use of article "the" and "a", and the lack of word choice in arranging words into meaningful noun phrase.

The example of wrong noun phrase: Child diligent correction: a diligent child Noun Adjective Ship big correction: the big ship Noun Adjective Side beach correction: the seashore Noun Noun, we assumed that some students still found difficulty in differentiating between noun and adjective, this error caused by mother tongue interference The second highest errors were 139 errors or $36,4 \%$ for verb phrase. It occured by students' lack to use the basic verb phrase such as the main verb and auxiliary.

And the students had wrong in the infinitive phrase form. The students didn't know as infinitive the word to must be followed by verb. It has functions as a noun, an adjective and also an adverb. The example: They live correction: they lived Verb2 His mother don't permit him correction: didn't permit him Auxiliary $\mathrm{He}$ wanted to repair his life correction he wanted to repair his life. To infinitive, we assumed the students found the difficulty to understand and apply tense rule in writing verb phrase, because Indonesian language does not have grammar rules and it's different with English. The third highest errors made by students were 42 errors or $11 \%$ for Adverbial Phrase. 
Most errors were caused by students' luck to find adverbial phrase that act as an adverb.

It modifies a verb, adverb or adjective and can tell "when", "how", "where" and "why". The highest errors of this level were made by students in describing the time and manner and constructing its word in adverbial phrase. The example of adverbial phrase error: In age formely: once upon a time Adv of time, With happy correction: happily adv of manner The fourth highest errors were 29 errors or 7,6 \% in adjective phrase. We analyzed the errors caused by students' lack in use kinds of to be before adjective.

In this case students didn't understand to arrange the appropriate tobe with the subject. The example of wrong adjective phrase: They very poor correction: they are very poor. His mother is sad correction: his mother was sad. The lowest number of errors in students' narrative writing text were 10 errors or 2,6\% for prepositional phrase.

In this test we found the students were only careless to write down the function of prepositional phrase as an adverb of place by using word "at". The example of prepositional phrase: They lived the seashore correction: they lived at the seashore. He wanted work the big ship correction: he wanted work in the big ship.

\section{CONCLUSION}

According to the explanation in the previous chapter, the writers conclude that the syntactical errors made by the second year students of SMP Nurul Hikmah II Bekasi in writing narrative text are in Noun Phrase for the highest errors by162 errors or $42,4 \%$, the second is errors in Verb Phrase by 139 errors or $36,4 \%$, the third is errors in Adverbial phrase by 42 errors or $11 \%$, the forth is errors in Adjective Phrase by 29 errors or $7,6 \%$ and the last errors in Prepositional Phrase with 6 errors or $30 \%$. Syntactical errors commonly happen because students' lack in mastering coherence, grammar and unity in their writing activity. In the future the teachers should do need analysis of what students' problem in English writing, and then identify what their problem so that the way to overcome their difficult can be done by the effective method.

To make the data clearer, here is the table of the percentage: Syntactical errors _Number of errors Percentage Adjective Phrase is $29(7,6 \%)$, Adverbial Phrase is 42 (11\%), Noun Phrase is $162(42,4 \%)$, Verb Phrase is 139 (36,4\%), Prepositional Phrase is 10 $(2,6 \%)$.

Errors in foreign language teaching especially in English are the cases which are difficult enough to avoid. Many aspects that can cause the learners of English as a foreign language make errors. To reduce the syntactical errors in students' writing, the students should learn more about Sentence Pattern, Tense, and Part of speech. For the English teachers, they should improve the way they teach and should improve their techniques in teaching by preparing systematic materials to reduce the errors which are always made by the learners.

They should encourage student to understand what a phrase is and to write phrases

which are appropriate to the register they are aiming for. after conducting interviews to teachers and students, the authors found that incomplete facilities in learning English such as the availability of limited reading material and student learning outcomes are still not satisfactory.

\section{REFERENCES}


Brinton, H. D. (2010). The Linguistic StructureKusumawardhani, P. (2015). Analysis of errors of Modern English, 2nd Eds. in writing the narrative composition of Amsterdam: John Benyamin Publishing English. Journal of Lingua Cultura, Company. $9(2)$.

Fromkin, V., Rodman, R., \& Hyams, N. (2006).

An Introduction to Language. Boston:Pallawa, B. A., \& Alam, A. F. A. (2013). A Wadsworth Publishing.

James, C. (2001). Errors Analysis and Error Correction in Language Teaching. UK: Cambridge University Press. Comparative Analysis between English and Indonesian Phonological Systems. International Journal of English Language, 1(3). 